\title{
Morphometric Effect of Erythropoietin Used as Doping and Swimming Exercise in Female Rats in Puberty on Humerus and Femur Bones
}

\author{
Mehmet ÖZDEMIR* \\ * Selçuk University Rectorate, Alaeddin Keykubat Campus, Akademi Mah. Yeni İstanbul Cad. No: 369 \\ Postal Code: 42130 \\ E-mail: ozdemirim69@gmail.com
}

\begin{abstract}
In this study, the effect of human erythropoietin (rhEPO) with aerobic exercise on the femur and humerus bone of female rats in the pubertal period was investigated by morphometric method. The study was performed on 40 female rats of the Spraque - Dawley genus.

The rats were divided into four groups as erythropoietin, swimming exercise with erythropoietin, swimming and sedentary. For 4 weeks, every other day all rats were injected with rhEPO (100 IU / kg, IP) 4 days a week. After the injection, the swimming group with rhEPO and the solo swimming group were swam for 30 minutes. At the end of 4 weeks, the rats were euthanized, and corpus, height and cortex and cavum medulla measurements of humerus and femur bones were done.

Statistical evaluation also indicated that there were no differences $(p>0.05)$ between rhEPO group, swimming group and rhEPO + swimming group femur length and femur cavum medulla da sedentary group. Sedentary group was found to be thicker $(\mathrm{p}<0.05)$ in femoral Corpus than swimming and rhEPO group, while there was no statistical difference in femoral cortex but a numerical difference was found.

While Humerus bone length and Corpus were not significant in our study ( $p>0.05)$, although the numerical values of rhEPO + swimming group in Cortex and Cavum medullada were different compared to other groups, no statistical difference was found $(\mathrm{p}>0.05)$. As a result, it is thought that long-term use of erythropoietin may cause bone development disorders.
\end{abstract}

Keywords: Doping, Erythropoietin, Exercise, Morphometry

DOI: $10.7176 /$ RHSS/10-9-08

Publication date:May $31^{\text {st }} 2020$ Special issue on science research

\section{Introduction}

It is well known that blood and bone share a unique, regulatory relationship with one another. But the details of the relationship between these two are still unanswered (McGee et al., 2012). Erythropoietin (EPO) is a hematopoietic growth factor that stimulates the formation of red blood cells. EPO is known as a doping agent in high-performance sports, and especially in cycling. In the clinical setting, this erythropoiesis stimulating agent is used to treat anemia, especially if it is caused by a lack of endogenous EPO production due to chronic kidney failure. In recent years, the non-hematopoietic functions of EPO, also known as pleiotropic functions, have been extensively investigated. Of interest for orthopedics and musculoskeletal tissue engineering, EPO's nonhematopoietic capabilities include osteogenic and angiogenic potencies (Rölfing, 2014).

For EPO's bone-forming role, the tissue may contain a protective hetereceptor ( Brines et al., 2004 ). However, Epo receptors ( Epo-R's) have been reported to be outside hematopoietic tissues, suggesting that EPO also plays a role in non-hematopoietic tissues (Mennini et al., 2006 ). The presence of Epo-R mRNAs has been reported in the brain, testes, placenta, heart, lungs, bone marrow and spleen ( Tan et al., 1991; Fandrey \& Bunn, 1993; Agnello et al., 2002 ; Brines \& Cerami, 2006 ).

The differential role of EPO on different organs indicates tissue-specific functions of EPO (Haroon, et al., 2003 ). The finding that EPO has pleiotropic roles in non-hematopoietic tissues has led to research into the role of EPO in bone formation and homeostasis ( Li \& Li, 2006; Wilson \& Trumpp, 2006; Yin \& Li, 2006 ). Therefore, combining hematopoiesis with skeletal homeostasis via Epo signaling makes important sense (Foldes et al., 1989 ; Gazit et al., 1990 ; Bab et al., 1992 ; Bab \& Einhorn, 1993 ; Bab, 1995; Greenberg et al., 1995 ). In their studies, Lee et al., (1991) showed that Epo therapy can increase cortical thickness.

Studies have repeatedly shown the morphological effect of EPO on bone, but the mechanisms that regulate the 
process remain unclear. One suggestion is that EPO may play an important role in regenerating newly absorbed bone by stimulating JAK-STAT signaling pathways through Epo-R in HSCs ( Shiozawa et al., 2010 ).

Among studies that observed bone formation in response to EPO, there are several notable major differences between those that did not. The first is the doses used. Supraphysiological doses are used in most studies showing bone formation. Those who used supraphysiological doses often used EPO doses that fell within a normal range. There may also be age-related differences in the animals ' response to EPO. We recorded that the reaction of young animals to EPO was more robust than the reaction in older animals (unpublished observations). Also, there are well-known differences in the hormonal response of different bones. For example, Singbrant et al. He studied the effects of EPO on the proximal tibia ( Singbrant et al., 2011 ).

Recent and ongoing studies show that hematopoietic stimulation improves bone formation in the context of both early ossification and fraction recovery and advances in mechanical strength (Ferguson et al., 1999; Brager et al., 2000; Bozler et al., 2006; Holstein et al., 2007).

The debate about the effects of EPO on bone formation still needs to be resolved. Also, there is much to learn about the molecular mechanisms of EPO and bone formation; is EPO's effects on the skeleton coupled with hematopoiesis or secondary to EPO's effects on hematopoiesis? If there is a direct effect on the skeleton, the HSC or MSC is the target or both, and both activities need to be present simultaneously for bone formation to occur (McGee et al., 2012).text text text text text

\section{Material And Method}

1- Subject Selection: 40 female Sprague-Dawley type rats from the Selçuk University Experimental Medicine Research and Application Center were used in the study.

Rats were housed in polycarbonate cages (Tecniplast, Italy) in a light-dark cycle of 14:10 hours at 21 \pm 2 CC, with 1 rat in $250 \mathrm{~cm} 2$ area, adlibitum was fed with standard rat feed (Purina, Canada) and water (normal tap water in glass bottles). The study was continued for 4 weeks.

Forming groups: the groups in the study were formed as follows.

1. Group (Drug Trial Group, $\mathrm{n}=10$ ). RhEPO for four weeks (EPOBEL ${ }^{\circledR} 2000 \mathrm{IU} / 0.6 \mathrm{~mL}$ LV, Nobel Pharmaceutical Marketing \& Industries Ltd. Şti) 100 IU / kg (Nuno et al 2009) dose was applied 4 times per week in peritoneal and 30 min swimming exercise was performed after each drug application.

2. Group (Swimming control group, $n=10$ ): rats were fed normally, given peritoneal saline 4 times per week and 30 min swimming exercise after each drug application.

3. Group (Drug Control Group, $n=10$ ). RhEPO was administered 4 times peritoneal times per week at a dose of $100 \mathrm{IU} / \mathrm{kg}$ for four weeks.

4. Group (healthy control group, $n=10$ ): the rats were fed normally.

At the end of the fourth week, the rats were euthanized by intraperitoneal injection of $200 \mathrm{mg} / \mathrm{kg}$ (Pentotal sodium, Abbott) of pentobarbital. The anterior and posterior extremities of the materials were then uncovered and dissected and subjected to maceration. The uncovered humerus and femur bones were marked and preserved in special plastic bags. Morphometric measurements of height length, Corpus, cortex and cavum medulla of humerus and femur bones, diameter were made from the reference points shown in figures 2.1 and 2.2. Measurements were taken with a stainless hardened digital caliper (China) caliper of 0-100 mm.

The images of the bones were taken with the Nikon DSLR D200. The statistical evaluation of the data was based on the package program SPSS 13.0 (SPSS 13.0 for Windows/ SPSS ${ }$ Inc, Chicago, USA). The results were presented as mean $\pm \mathrm{Sd}$. Anova and Duncan test were used to compare the data between groups. $\mathrm{p}<0.05$ value was considered statistically significant. 
Picture 2.1. Reference points of length (L), Corpus (C), Cortex (C1-C2) and Medullar diameters (M) of humerus

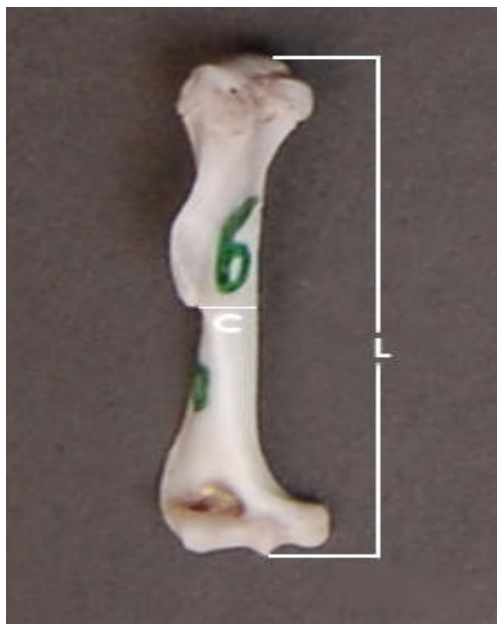

L: distance between endpoints of Caput humer and trochlea humer.C: corpus of humerus thickness (lower border level of Tuberositas deltoidea).

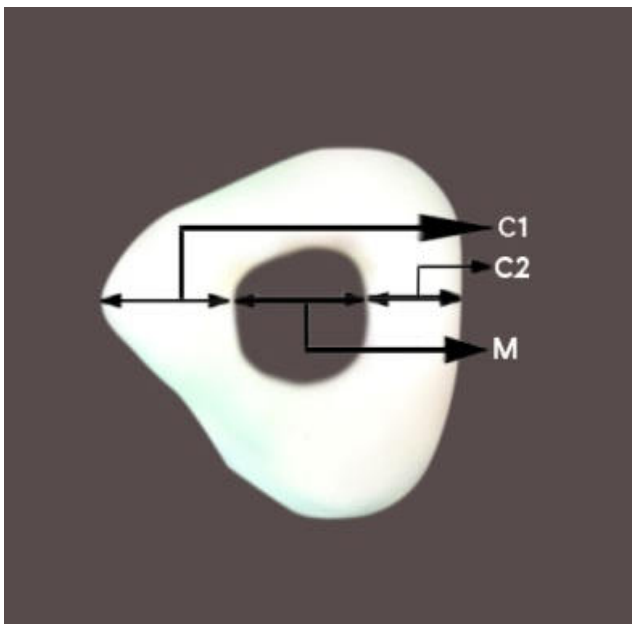

C1 - C2: mean cortex thickness (cortical bonesubstantia) at the corpus level of the humerus compacta).

M: diameter of cavum medullare at the corpus level of humerus.

Pictures 2.2. Reference points of femur length (L), Corpus (C), Cortex (C1-C2) and Medullar diameters (M)

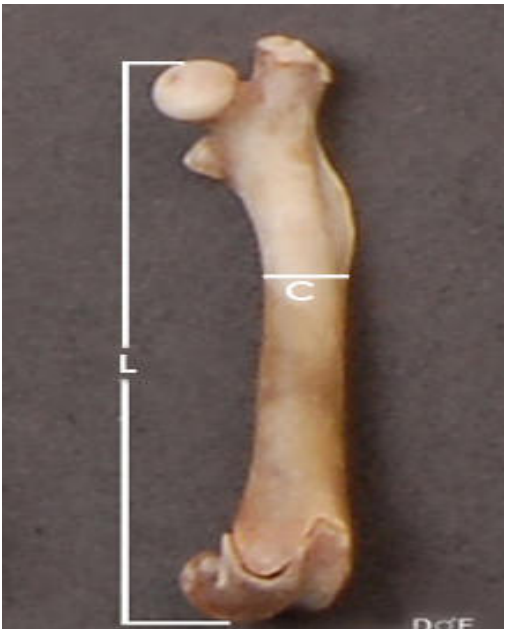

$\mathrm{L}$ : distance between caput ossis femoris and endpoints of trochlea ossis femoris.

$\mathrm{C}$ : thickness of the femur's corpus (lower bound level of the Trochanter Tertius).

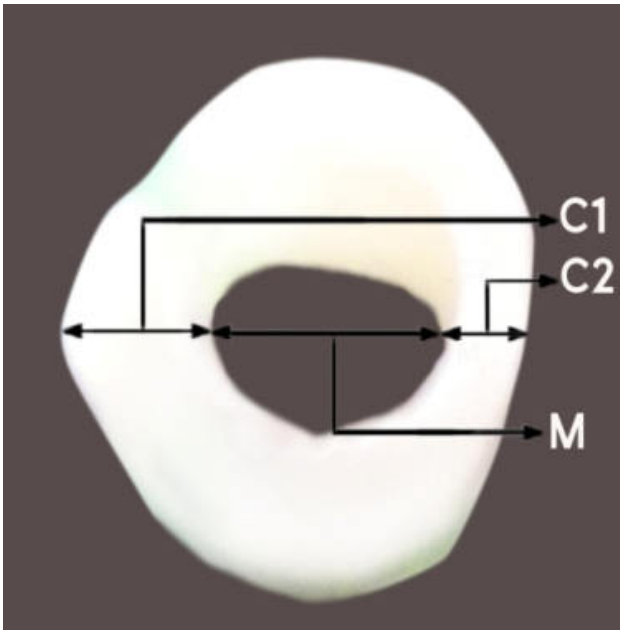

C1-C2: the mean cortex thickness at the corpus level of the femur (cortical bone substantia compacta)

M: diameter of cavum medullare at corpus level of femur. 


\section{Results}

Tab. 1 .

Morphometric Effect of Erythropoietin Used as Swimming Exercise and Doping on Humerus and Femur Bones in Female Puberty Period ( $\mathrm{mm})(\mathrm{Mean} \pm \mathrm{Sd})$.

\begin{tabular}{|c|c|c|c|c|c|c|}
\hline & rhEPO & $\begin{array}{c}\text { rhEPO + } \\
\text { Swimming }\end{array}$ & Swimming & Sedentary & $\mathrm{F}$ & $\mathrm{P}$ \\
\hline $\begin{array}{l}\text { Corpus } \\
\text { Femoris }\end{array}$ & $3.93 \pm .14^{\mathrm{b}}$ & $\begin{array}{c}4.02 \\
\pm .18^{\mathrm{ab}}\end{array}$ & $3.90 \pm .19^{b}$ & $4.16 \pm .15^{\mathrm{a}}$ & 5.075 & $.005^{*}$ \\
\hline Femur Length & $\begin{array}{r}30.63 \\
\pm .39 \\
\end{array}$ & $\begin{array}{l}31.02 \\
\pm .99 \\
\end{array}$ & $30.36 \pm 1.03$ & $\begin{array}{l}30.84 \\
\pm .39 \\
\end{array}$ & 1.389 & .262 \\
\hline Femur Cortex & $.83 \pm .11$ & $.88 \pm .12$ & $.93 \pm .14$ & $.95 \pm .09$ & 2.163 & .109 \\
\hline $\begin{array}{l}\text { Femur Cavum } \\
\text { Medulla }\end{array}$ & $2.62 \pm .21$ & $2.28 \pm .21$ & $2.05 \pm .38$ & $2.24 \pm .18$ & 1.664 & .192 \\
\hline Corpus Humeri & $2.94 \pm .13$ & $2.95 \pm .08$ & $2.86 \pm .11$ & $2.93 \pm .23$ & .807 & .498 \\
\hline $\begin{array}{l}\text { Humerus } \\
\text { Length }\end{array}$ & $\begin{array}{l}24.17 \\
\pm .40\end{array}$ & $\begin{array}{l}24.32 \\
\pm .66\end{array}$ & $24.02 \pm .46$ & $\begin{array}{l}24.27 \\
\pm .52\end{array}$ & .672 & .575 \\
\hline $\begin{array}{c}\text { Humeral } \\
\text { Cortex }\end{array}$ & $.77 \pm .11$ & $.82 \pm .09$ & $.75 \pm .11$ & $.76 \pm .08$ & 1.042 & .386 \\
\hline $\begin{array}{l}\text { Humerus } \\
\text { Cavum } \\
\text { Medulla }\end{array}$ & $1.37 \pm .26$ & $1.33 \pm .18$ & $1.37 \pm .20$ & $1.45 \pm .24$ & .513 & .676 \\
\hline
\end{tabular}

$* \mathrm{P}<0.05 . \mathrm{a}, \mathrm{b}, \mathrm{c}$, There are significant differences between values carrying different letters in the same line (p $<0.05)$

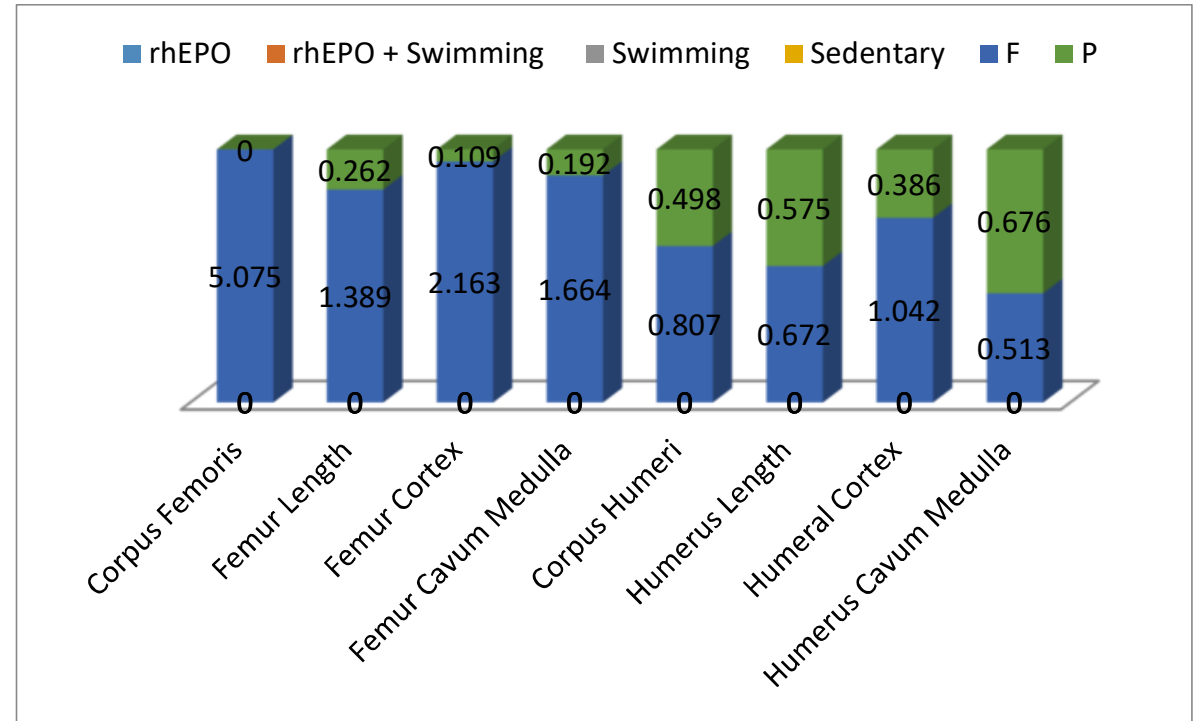

Grafic1. Morphometric effect of erythropoietin on humerus and Femur Bones $(\mathrm{mm})(\mathrm{Mean} \pm \mathrm{Sd})$ used as swimming exercise and Doping in female rats during Puberta period.

it is stated that there are no differences $(\mathrm{p}>0.05)$ between rhEPO group, swimming group and rhEPO + swimming group femur length, femur cavum medulla da sedentary group. Sedentary group was found to be thicker $(\mathrm{p}<0.05)$ in femoral Corpus than swimming and rhEPO Grun, but no statistical difference was found in femoral cortex.

While Humerus bone length and Corpus were not significant in our study ( $>0.05)$, although the numerical values of rhEPO + swimming group in Cortex and Cavum medullada were different compared to other 
groups, no statistical difference was found $(\mathrm{p}>0.05)$.

\section{Discussion}

The bone that forms the basis of skeletal mobility is a dynamic organ that plays a variety of roles in the body ( Anjos-Afonso \& Bonnet, 2007 ). EPO bone creation may also include a hetereceptor that protects tissue (Brines, et al., 2004 ). EPO supplementation may increase cortical thickness in bone (Lee et al., 1991 ). EPO can improve bone formation (Ferguson et al., 1999; Brager et al., 2000; Bozler et al., 2006; Holstein et al., 2007). In their study, Sakunya et al., (2019) states that EPO therapy makes thickening in the corpus by regulating low bone mass in long bones. In our study, it was determined that the sedentary group was thicker $(\mathrm{p}<0.05)$ in femoral Corpus than in swimming and rhEPO group, while there was no statistical difference in femoral cortex but a numerical difference was found. Özdemir, (2013) reports that the widest corpus femoris $(\mathrm{p}<0.05)$ measurement was determined in the sedentary group.

In another study, Röfling, (2014) in his study on bone fracture recovery in mice, states that EPO increases bone volume and decreases bone marrow cavity. After methanolone enanthate application to adolescent rats, Bozkurt et al., (2011) found that there was a significant $(\mathrm{p}<0.05)$ thinning of the corpus femorist while finding that there was a significant $(\mathrm{p}<0.05)$ shortening of the femur length.

In our study, the length and Corpus of humerus bone were not significant ( $p>0.05)$, although the numerical values of rhEPO + swimming group in Cortex and Cavum medullada were different compared to other groups, no statistical difference was found ( $\mathrm{p}>0.05$ ). In their study, Lavoie et al., (1998) examined the effect of anaerobic exercise on rat metabolism by using rhEPO supplementation and found that rhEPO contributes to bone tissue in a low proportion. Mohammadian et al., (2003) noted that the increase in iron load made growth retardation in bone particularly apparent in the age of puberta. Similarly, Low., (1997) stated that it inhibits growth in bone in his study looking at growth functions in beta-thalassemia patients.

Low bone mineral density in some elite athletes suggests that intense exercise may have negative effects (Hatun, 2000). There are studies that show that high intensity exercises performed before and during puberta have positive or negative effects on growth and skeletal development. Studies on this subject show that girls with rhythmic gymnastics are shorter and weaker than their peers in other sports and non-sports (Benardot \& Czerwinski 1991, Damsgaard et al., 2000). Akin et al., (2004) reported that in their study with rhythmic gymnasts before puberta, intense exercise is shortening in the neck of gymnasts and thinning in bone thickness.

\section{Conclusion}

As a result, while rhEPO, commonly used as a doping agent in recent years, not only improves performance but provides positive effects in bone forty repairs in the long term, its negative effects on healthy bone tissue have been tried to be explained by rat models. Although the effects of rhEPO and intense exercise on bone development have not been demonstrated, further studies are needed to reveal their effects on other organs. 


\section{Acknowledgments}

I thank to Selcuk University, Faculty of Veterinary Medicine, Professor Dr. Enver YAZAR, Associate Professor. Özgür ÖZDEMİ, Professor of Sport Sciences Faculty. Dr. İbrahim BOZKURT

\section{References}

Agnello, D., Bigini, P., Villa, P., Mennini, T., Cerami, A., Brines, M.L, \& Ghezzi, P. (2002). Erythropoietin exerts an anti-inflammatory effect on the CNS in a model of experimental autoimmune encephalomyelitis. Brain research. 1:128-134.

Akın S, Ersöz, G., \& Bulca, Y. (2004). Puberte Öncesi Ritmik Cimnastik Sporcularında Fiziksel Aktivite ve Vücut Kompozisyonunun Kemik Mineral Yoğunluğuna Etkisi.Türkiye Fiziksel Tıp ve Rehabilitasyon Dergisi, (50)3.

Anjos-Afonso, F., \& Bonnet, D. (2007). Flexible and dynamic organization of bone marrow stromal compartment. British journal of haematology. 3:373-384.

Bab, I., Gazit, D., Chorev, M., Muhlrad, A., Shteyer, A., Greenberg, Z., Namdar, M., \& Kahn , A. (1992). Histone $\mathrm{H} 4$ related osteogenic growth peptide (OGP): a novel circulating stimulator of osteoblastic activity. The EMBO journal. 5:1867-1873.

Bab, I.A., \& Einhorn, T.A. (1993). Regulatory role of osteogenic growth polypeptides in bone formation and hemopoiesis. Critical reviews in eukaryotic gene expression. 1:31-46.

Bab, I.A. (1995). Postablation bone marrow regeneration: an in vivo model to study differential regulation of bone formation and resorption. Bone. 4(1):437-441.

Benardot, D., \& Czerwinski, C. (1991). Selected body composition and growth measures of junior elite gymnasts. J Am Diet Assoc 91: 29-33.

Bozkurt, I., Pepe, K., Ozdemir, M., Ozdemir, O., \& Coskun, A. (2011). Morphometric evaluation of the effect of methenolone enanthate on femoral development in adolescent rats. Scientific Research and Essays, 6(7),1634-1638.

Bozlar M, Kalaci A, Aslan B, Baktiroglu L, Yanat AN, \&Tasci A. (2006). Effects of erythropoietin on fracture healing in rats. Saudi medical journal. 8:1267-1269.

Brager, M.A., Patterson, M.J., Connolly, J.F., \& Nevo, Z. (2000). Osteogenic growth peptide normally stimulated by blood loss and marrow ablation has local and systemic effects on fracture healing in rats. Journal of orthopaedic research: official publication of the Orthopaedic Research Society. 1:133- 139.

Brines, M., \& Cerami, A. (2006). Discovering erythropoietin's extra-hematopoietic functions: biology and clinical promise. Kidney international. 2:246-250.

Brines, M., Grasso, G., Fiordaliso, F., Sfacteria, A., Ghezzi, P., Fratelli, M., Latini, R., Xie, Q.W., Smart, J., SuRick, C.J., Pobre, E., Diaz, D., Gomez, D., Hand, C., Coleman, T., \& Cerami, A. (2004).Erythropoietin mediates tissue protection through an erythropoietin and common beta-subunit heteroreceptor. Proceedings of the National Academy of Sciences of the United States of America. 41:14907-14912.

Damsgaard, R., Bencke, J., Matthiesen, G., Petersen, J.H., \& Müller, J. (2000). Is prepubertal growth adversely affected by sport? Med Sci Sports Exerc, 32:10, 1698-703.

Fandrey, J. \& Bunn, H.F. (1993). In vivo and in vitro regulation of erythropoietin mRNA: measurement by competitive polymerase chain reaction. Blood. 3:617-623.

Ferguson C., Alpern, E., Miclau, T., \& Helms, J.A. (1999). Does adult fracture repair recapitulate embryonic skeletal formation? Mechanisms of development. 1-2:57-66.

Foldes, J., Naparstek, E., Statter, M., Menczel, J., \& Bab, I. (1989). Osteogenic response to marrow aspiration: increased serum osteocalcin and alkaline phosphatase in human bone marrow donors. Journal of bone and mineral research: the official journal of the American Society for Bone and Mineral Research. 4:643-646.

Gazit, D., Karmish, M., Holzman, L., \& Bab, I. (1990). Regenerating marrow induces systemic increase in osteoand chondrogenesis. Endocrinology. 5:2607-2613.

Greenberg, Z., Chorev, M., Muhlrad, A., Shteyer, A., Namdar-Attar, M., Casap, N., Tartakovsky, A., Vidson, M., \& Bab, I. (1995). Structural and functional characterization of osteogenic growth peptide from human serum: identity with rat and mouse homologs. The Journal of clinical endocrinology and metabolism. $8: 2330-2335$.

Haroon, Z.A., Amin, K., Jiang, X., \&Arcasoy, M.O. (2003). A novel role for erythropoietin during fibrin-induced wound-healing response. The American journal of pathology. 3:993-1000. 
Hatun, Ş. (2000). Çocuklarda Kemik Sağlı̆̆ı. Sürekli Tıp Ĕ̌̆itimi dergisi,9,5, [cited 2020 Mayıs 22]. Available from URL: https://www.ttb.org.tr/STED/sted0500/05001.html

Holstein, J.H., Menger, M.D., Scheuer, C., Meier, C., Culemann, U., Wirbel, R.J., Garcia, P.,\& Pohlemann, T. (2007). Erythropoietin (EPO): EPO-receptor signaling improves early endochondral ossification and mechanical strength in fracture healing. Life sciences. 10:893-900.

Lavoie, C., Diguet, A., Milot M., \& Gareau, R. (1998).Erythropoietin (rHuEPO) Doping: Effects of Exercise on Anaerobic Metab,olism in Rats. Int J Sports Med. 19(4): 281-286

Lee, M.Y., Fukunaga, R., Lee, T.J., Lottsfeldt, J.L., \& Nagata, S. (1991). Bone modulation in sustained hematopoietic stimulation in mice. Blood. 10:2135-2141.

Li, Z., \& Li, L. (2006). Understanding hematopoietic stem-cell microenvironments. Trends in biochemical sciences. 10:589-595.

Low, L.C. (1997).Growth, puberty and endocrine function in beta-thalassaemia major. J Pediatr Endocrinol Metab.10: 175-184.

McGee, S.J., Havens, A.M., Shiozawa, Y., Jung, Y., \& Taichman, R.S. (2012). Effects of Erythropoietin on the Bone Microenvironment. National Institutes of health, (NIH Public Access); 30(1): 22-28. doi:10.3109/08977194.2011.637034

Mennini, T., De Paola, M., Bigini, P., Mastrotto, C., Fumagalli, E., Barbera, S., Mengozzi, M., Viviani, B., Corsini, E., Marinovich, M., Torup, L., Van Beek, J., Leist, M., Brines, M., Cerami, A., \& Ghezzi, P. (2006). Nonhematopoietic erythropoietin derivatives prevent motoneuron degeneration in vitro and in vivo. Molecular medicine. 7-8:153-160.

Mohammadian, S., Bazrafshan, H.R., Sadeghi-Nejad, A. (2003). Endocrine gland abnormalities in thalassemia major: a brief review. J Pediatr Endocrinol Metab. 16:957-64.

Özdemir, M. (2013). The Morphometric Effect Of Erythropoietin Used As A Doping Agent On The Humerus And Femur Bones Of Pubescent Male Rats Maintained Sedentary Or Submitted To Swimming Exercise. International Journal Of Academic Research Part A, 52(2), 166-171.,

Rölfing, J.H.D. (2014) The effect of erythropoietin on bone, Acta Orthopaedica, 85:sup353, 1-29, DOI: $10.3109 / 17453674.2013 .869716$

Shiozawa, Y., Jung, Y., Ziegler, A.M., Pedersen, E.A., Wang, J., Wang, Z., Song, J., Lee, C.H., Sud, S., Pienta, K.J., Krebsbach, P.H., \& Taichman, R.S. (2010). Erythropoietin couples hematopoiesis with bone formation. PloSone. 5:10853.

Singbrant, S., Russell, M.R., Jovic, T., Liddicoat, B., Izon, D.J., Purton, L.E., Sims, N.A., Martin, T.J, Sankaran, V.G., \& Walkley, C.R. (2011). Erythropoietin couples erythropoiesis, B-lymphopoiesis, and bone homeostasis within the bone marrow microenvironment. Blood. 21:5631-5642.

Sukanya, S., Luis, F.C., Soumyadeep, D., Pamela, G.R., \& Constance, T.N. (2019) Erythropoietin modulates bone marrow stromal cell differentiation, Bone Research, 7:21; doi.org/10.1038/s41413-019-0060-0

Tan, C.C., Eckardt, K.U., \& Ratcliffe, P.J. (1991).Organ distribution of erythropoietin messenger RNA in normal and uremic rats. Kidney international. 1:69-76.

Wilson, A., \& Trumpp, A. (2006). Bone-marrow haematopoietic-stem-cell niches. Nature reviews. Immunology. 2:93-106.

Yin, T., \& Li, L. (2006). The stem cell niches in bone. The Journal of clinical investigation. 5:1195-1201. 
Tab. 1.

Morphometric Effect of Erythropoietin Used as Swimming Exercise and Doping on Humerus and Femur Bones in Female Puberty Period $(\mathrm{mm})($ Mean $\pm \mathrm{Sd})$.

\begin{tabular}{|c|c|c|c|c|c|c|}
\hline & rhEPO & $\begin{array}{c}\text { rhEPO + } \\
\text { Swimming }\end{array}$ & Swimming & Sedentary & $\mathrm{F}$ & $\mathrm{P}$ \\
\hline $\begin{array}{c}\text { Corpus } \\
\text { Femoris }\end{array}$ & $3.93 \pm .14^{b}$ & $\begin{array}{c}4.02 \\
\pm .18^{\mathrm{ab}}\end{array}$ & $3.90 \pm .19^{\mathrm{b}}$ & $4.16 \pm .15^{\mathrm{a}}$ & 5.075 & $.005^{*}$ \\
\hline Femur Length & $\begin{array}{l}30.63 \\
\pm .39\end{array}$ & $\begin{array}{l}31.02 \\
\pm .99\end{array}$ & $30.36 \pm 1.03$ & $\begin{array}{l}30.84 \\
\pm .39\end{array}$ & 1.389 & .262 \\
\hline Femur Cortex & $.83 \pm .11$ & $.88 \pm .12$ & $.93 \pm .14$ & $.95 \pm .09$ & 2.163 & .109 \\
\hline $\begin{array}{l}\text { Femur Cavum } \\
\text { Medulla }\end{array}$ & $2.62 \pm .21$ & $2.28 \pm .21$ & $2.05 \pm .38$ & $2.24 \pm .18$ & 1.664 & .192 \\
\hline Corpus Humeri & $2.94 \pm .13$ & $2.95 \pm .08$ & $2.86 \pm .11$ & $2.93 \pm .23$ & .807 & .498 \\
\hline $\begin{array}{l}\text { Humerus } \\
\text { Length }\end{array}$ & $\begin{array}{l}24.17 \\
\pm .40\end{array}$ & $\begin{array}{l}24.32 \\
\pm .66\end{array}$ & $24.02 \pm .46$ & $\begin{array}{l}24.27 \\
\pm .52\end{array}$ & .672 & .575 \\
\hline $\begin{array}{l}\text { Humeral } \\
\text { Cortex }\end{array}$ & $.77 \pm .11$ & $.82 \pm .09$ & $.75 \pm .11$ & $.76 \pm .08$ & 1.042 & .386 \\
\hline $\begin{array}{l}\text { Humerus } \\
\text { Cavum } \\
\text { Medulla }\end{array}$ & $1.37 \pm .26$ & $1.33 \pm .18$ & $1.37 \pm .20$ & $1.45 \pm .24$ & .513 & .676 \\
\hline
\end{tabular}

* $\mathrm{P}<0.05 . \mathrm{a}, \mathrm{b}, \mathrm{c}$, There are significant differences between values carrying different letters in the same line (p $<0.05$ )

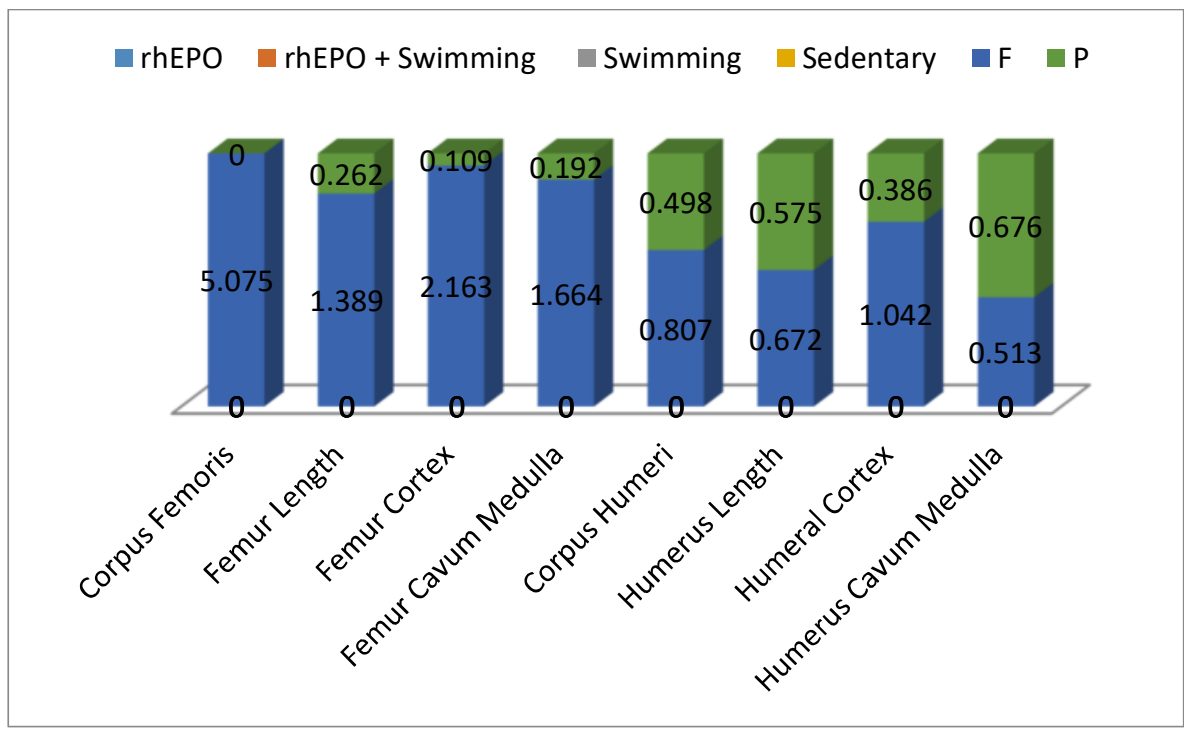

Grafic1. Morphometric effect of erythropoietin on humerus and Femur Bones (mm) (Mean \pm Sd) used as swimming exercise and Doping in female rats during Puberta period. 